Fetal Diagnosis and Therapy
Fetal Diagn Ther 2010;27:204-213

DOI: $\underline{10.1159 / 000299475}$
Received: January 5, 2010

Accepted after revision: March 14, 2010

Published online: June 3, 2010

\title{
Performance of 36 Different Weight Estimation Formulae in Fetuses with Macrosomia
}

\author{
Markus Hoopmann Harald Abele Norbert Wagner Diethlem Wallwiener \\ Karl O. Kagan \\ Department of Obstetrics and Gynaecology, University of Tuebingen, Tuebingen, Germany
}

\section{Key Words}

Fetal weight estimation $\cdot$ Birth weight $\cdot$ Macrosomia $\cdot$

Accuracy, prenatal

\begin{abstract}
Introduction: The aim of this retrospective clinical study was to compare the accuracy of 36 commonly used weight estimation formulae in macrosomic fetuses. Material and Methods: Ultrasound estimation of fetal weight (FW) was carried out within 7 days up to delivery in 350 singleton fetuses with a birth weight (BW) of $\geq 4,000 \mathrm{~g}$. The accuracy of the different formulae for FW estimation was compared by, firstly, the mean percentage (MPE) and mean absolute percentage error (MAPE), secondly, by the frequency distribution of differences between estimated FW and fetal BW, and thirdly by comparing detection and false positive rates in screening for fetuses with a BW of 4,000, 4,300 and 4,500 g or more. Results: MPE ranged from -62.2 to $9.6 \%$ and was closest to 0 with the Hart formula. With 12 of 36 weight estimation formulae, MAPE was $10 \%$ or less, and was smallest with the Hart formulae (3.9\%). The mean detection rate among all formulae for fetuses with a BW $\geq 4,000, \geq 4,300$ and $\geq 4,500 \mathrm{~g}$ was 29,24 and $22 \%$, respectively, and the false positive rate was $12 \%$ (for $\geq 4,300 \mathrm{~g}$ ) and $7 \%$ ( $\geq 4,500 \mathrm{~g}$ ). Discussion: Some
\end{abstract}

\section{KARGER}

Fax +4161306 1234

E-Mail karger@karger.ch

www.karger.com (c) 2010 S. Karger AG, Basel

$1015-3837 / 10 / 0274-0204 \$ 26.00 / 0$

Accessible online at:

www.karger.com/fdt formulae showed advantages as far as mean and absolute percentage errors were concerned, but none reached a detection rate and false positive rate for fetuses $\geq 4,500 \mathrm{~g}$ that could lead to clinical recommendation.

Copyright $\odot 2010$ S. Karger AG, Basel

\section{Introduction}

It is widely accepted that pregnancies with macrosomic fetuses have an increased risk for shoulder dystocia, brachial plexus injury, asphyxia, prolonged labour, surgical delivery and postpartum haemorrhage [1]. However, there is an ongoing controversy regarding the definition and antenatal prediction of macrosomic fetuses [2]. Some authors favour a fetal weight (FW) of 4,000 or $4,500 \mathrm{~g}$ or more, others prefer a centile-based threshold around the 90 th or 95 th centile [3-5]. In addition, there is no consensus whether the decision about macrosomia should be based on the fetal birth weight (FBW) or on the estimated FW (EFW).

M.H. and H.A. contributed equally to this study. 
If a macrosomic fetus is clinically suspected, it is good practise to perform an ultrasound examination to estimate FW. For this purpose, regression formulae were developed within the last four decades which combine a certain number of easy and reproducible two-dimensional (2D) fetal measurements [6]. This estimation of FW has substantial impact on the further obstetric management as the fetomaternal risks raise with increasing FW. In view of the shoulder dystocia, the risk is about $0.2 \%$ in average sized fetuses. With a BW of 4,000-4,500 g, this risk increases to about 5\% and it is about 30\% above 4,500 g, respectively [7-9]. This association is of high forensic impact. Thus, obstetricians tend to counsel towards early induction of labour or caesarean section based on the results of the FW estimation [2]. These problems have become more obvious within the last years due to an increase in the FW [10].

In contrast to the high clinical impact the accuracy of FW estimation is low in macrosomic fetuses. Several studies demonstrated errors exceeding $10 \%$ of the BW or $500 \mathrm{~g}$ in macrosomic fetuses $[11,12]$. The aim of our study was to compare 36 commonly used formulae on their accuracy in estimating FW in fetuses of 4,000 g or more. The study focuses on the performance of each formula in detecting fetuses with a BW above critical thresholds of $4,000,4,300$ and $4,500 \mathrm{~g}$.

\section{Material and Methods}

For this retrospective study, the perinatal computer database was searched for all singleton pregnancies that resulted in a liveborn fetus without structural or chromosomal defects with a BW of $4,000 \mathrm{~g}$ or more. As part of the routine perinatal management at the Department of Obstetrics and Gynaecology of the University of Tuebingen, every pregnant woman received an ultrasound examination shortly before delivery. In general, during this examination, fetal presentation was confirmed, amniotic fluid volume was assessed and FW (EFW) was estimated on the basis of one of the common weight estimation formulae. The biparietal and occipito-frontal diameters were measured at the transventricular level from the outer edge to the outer edge of the skull bone. The head circumference (HC) was either measured or calculated $(\mathrm{HC}=2.325 \times(($ occipito-frontal diameter $) \wedge 2+($ biparietal diameter $\left.\left.)^{\wedge} 2\right)^{\wedge} 1 / 2\right)$. The fetal abdominal transverse and antero-posterior diameters were measured at the level of the stomach and umbilical vein-ductus venosus complex. The abdominal circumference $(\mathrm{AC})$ was calculated $(\mathrm{AC}=\pi \times$ (transverse diameter $(\mathrm{ATD})+$ antero-posterior diameter $(\mathrm{APD})) / 2)$. The femur length (FL) was measured from the proximal end of the greater trochanter to the distal metaphysis. The individual measurements ( $\mathrm{mm})$, FBW (g) and the maternal demographic characteristics were recorded into a perinatal computer database. BW was assessed immediately after delivery by either the midwife, obstetrician or paediatrician.

In each of the included pregnancies the last ultrasound examination was identified which included the measurement of the biparietal and fronto-occipital diameter of the head, the anteroposterior and the transverse diameter of the abdomen and the femur length. Pregnancies with incomplete data or those pregnancies where the last ultrasound examination was not performed within 7 days before delivery were excluded from further analysis. Each pregnancy that fulfilled the inclusion criteria was only included once in the database.

\section{Statistical Analysis}

In each case the EFW was calculated on the basis of the published formulae from Birnholz, Combs, Campbell, Ferrero, Hadlock, Halaska, Hansmann, Hart, Higginbottom, Jordaan, Persson, Merz, Mielke, Ott, Rose and McCallum, Sabbagha, Schild, Schillinger, Scott, Shepard, Shinozuka, Siemer, Thurnau, Vintzileos, Warsof, Weiner and Woo [13-42]. A list of the tested 36 formulae is shown in table 1.

The accuracy of the different formulae for FW estimation was assessed and compared by (1) mean percentage error (MPE = $(\mathrm{EFW}-\mathrm{BW}) / \mathrm{BW} \times 100)$ and mean absolute percentage error $(\mathrm{MAPE}=(|\mathrm{EFW}-\mathrm{BW}| / \mathrm{BW} \times 100)) . \mathrm{MPE}$ was considered as marker for the systematic error, the corresponding standard deviation as marker for the random error, respectively. The $95 \%$ confidence intervals (CI) for the MPE were calculated as mean \pm $1.96 \times$ standard error and were used to test for a significant difference from 0 . In addition, differences were compared by $95 \%$ limits of agreement according to the method described by Bland and Altman. (2) Frequency distribution of differences between EFW and BW: differences were calculated as $\mid$ EFW - BW|/BW and demonstrated as the proportion of cases with a discrepancy within $\pm 5, \pm 10, \pm 20$ and $\pm 30 \%$. (3) Detection and false positive rates in screening for fetuses with a BW of $\geq 4,000,4,300$ and $4,500 \mathrm{~g}$. The rates were calculated by taking the proportion of cases on and above certain thresholds.

\section{Results}

The search of the database identified 350 cases between 2004 and 2008 fulfilling the inclusion criteria. A summary of the maternal and fetal characteristics is given in table 2.

Mean Percentage Error and Absolute Percentage Error

MPE and MAPE for each of the 36 weight estimation formulae are shown in table 3. MPE was smallest with the Mielke I formula (MPE $-62.2 \%$ ), biggest with the Merz II formula (MPE 9.6\%) and closest to 0 with the Hart formula (MPE 0.3\%), respectively. The standard deviation of the MPE was between 4.1 (Siemer) and $18.2 \%$ (Hadlock IV) and it was $4.8 \%$ with the Hart formula, respectively. Only with the latter and with the 
Table 1. Regression models for fetal weight estimation

\begin{tabular}{|c|c|c|}
\hline First author & Components & Formula \\
\hline Combs [37] & $\mathrm{HC}, \mathrm{AC}, \mathrm{FL}$ & $0.23718 * \mathrm{AC}^{\wedge} 2 * \mathrm{FL}+0.03312 * \mathrm{HC}^{\wedge} 3[\mathrm{~g}, \mathrm{~cm}]$ \\
\hline Ferrero [39] & $\mathrm{AC}, \mathrm{FL}$ & $\begin{array}{l}10^{\wedge}\left(0.77125+0.13244 * \mathrm{AC}-0.12996 * \mathrm{FL}-1.73588^{*} \mathrm{AC} \wedge 2 / 1,000+3.09212 * \mathrm{FL}^{*}\right. \\
\mathrm{AC} / 1,000+2.18984 * \mathrm{FL} / \mathrm{AC})[\mathrm{g}, \mathrm{cm}]\end{array}$ \\
\hline Hadlock I [41] & $\mathrm{BPD}, \mathrm{HC}, \mathrm{AC}, \mathrm{FL}$ & $\begin{array}{l}10^{\wedge}\left(1.3596+0.0064 * \mathrm{HC}+0.0424 * \mathrm{AC}+0.174 * \mathrm{FL}+0.00061^{*} \mathrm{BPD}{ }^{*} \mathrm{AC}-0.00386\right. \\
\left.{ }^{*} \mathrm{AC}{ }^{*} \mathrm{FL}\right)[\mathrm{g}, \mathrm{cm}]\end{array}$ \\
\hline Hadlock III [41] & $\mathrm{BPD}, \mathrm{AC}, \mathrm{FL}$ & $10^{\wedge}\left(1.335-0.0034 * \mathrm{AC} * \mathrm{FL}+0.0316^{*} \mathrm{BPD}+0.0457 * \mathrm{AC}+0.1623 * \mathrm{FL}\right)[\mathrm{g}, \mathrm{cm}]$ \\
\hline Hadlock IV [41] & $\mathrm{HC}, \mathrm{AC}, \mathrm{FL}$ & $10^{\wedge}\left(1.326-0.00326 * \mathrm{AC}{ }^{*} \mathrm{FL}+0.0107 * \mathrm{HC}+0.0438 * \mathrm{AC}+0.158 * \mathrm{FL}\right)[\mathrm{g}, \mathrm{cm}]$ \\
\hline Hadlock V [40] & $\mathrm{BPD}, \mathrm{AC}$ & $\begin{array}{l}10^{\wedge}\left(1.1134+0.05845^{*} \mathrm{AC}-0.000604 * \mathrm{AC}^{\wedge} 2-0.007365^{*} \mathrm{BPD}^{\wedge} 2+0.000595 * \mathrm{BPD}^{*}\right. \\
\left.\mathrm{AC}+0.1694^{*} \mathrm{BPD}\right)[\mathrm{g}, \mathrm{cm}]\end{array}$ \\
\hline Hadlock VI [40] & $\mathrm{HC}, \mathrm{AC}, \mathrm{FL}$ & $\begin{array}{l}10^{\wedge}\left(1.5662-0.0108 * \mathrm{HC}+0.0468 * \mathrm{AC}+0.171 * \mathrm{FL}+0.00034 * \mathrm{HC}^{\wedge} 2-0.0003685 * \mathrm{AC}\right. \\
\left.{ }^{*} \mathrm{FL}\right)[\mathrm{g}, \mathrm{cm}]\end{array}$ \\
\hline Hart [42] & $\mathrm{HC}, \mathrm{AC}, \mathrm{FL}, \mathrm{MW}$ & $\begin{array}{l}\mathrm{e}^{\wedge} 7.6377445039+0.0002951035 * \mathrm{MW}+0.0003949464 * \mathrm{HC}+0.0005241529 * \mathrm{AC}+ \\
0.0048698624 * \mathrm{FL}[\mathrm{g}, \mathrm{mm}]\end{array}$ \\
\hline Higginbottom [15] & $\mathrm{AC}$ & $0.0816 * \mathrm{AC}^{\wedge} 3[\mathrm{~g}, \mathrm{~cm}]$ \\
\hline Jordaan [16] & $\mathrm{BPD}, \mathrm{HC}, \mathrm{AC}$ & $10^{\wedge}(2.3231+0.02904 * \mathrm{AC}+0.0079 * \mathrm{HC}-0.0058 * \mathrm{BPD})[\mathrm{kg}, \mathrm{cm}]$ \\
\hline Merz I [18] & $\mathrm{BPD}, \mathrm{AC}$ & $-3,200.40479+157.07186 * \mathrm{AC}+15.90391 * \mathrm{BPD}^{*} \mathrm{BPD}[\mathrm{g}, \mathrm{cm}]$ \\
\hline Merz II [18] & $\mathrm{AC}$ & $0.1 * \mathrm{AC}^{\wedge} 3[\mathrm{~g}, \mathrm{~cm}]$ \\
\hline Ott [21] & $\mathrm{HC}, \mathrm{AC}, \mathrm{FL}$ & $\begin{array}{l}10^{\wedge}\left(-2.0661+0.04355 * \mathrm{HC}+0.05394 * \mathrm{AC}-0.0008582 * \mathrm{HC}^{*} \mathrm{AC}+1.2594 * \mathrm{FL} / \mathrm{AC}\right) \\
{[\mathrm{kg}, \mathrm{cm}]}\end{array}$ \\
\hline Rose [22] & $\mathrm{BPD}, \mathrm{AD}, \mathrm{FL}$ & $\mathrm{e}^{\wedge}\left(0.143^{*}(\mathrm{BPD}+\mathrm{AD}+\mathrm{FL})+4.198\right)[\mathrm{g}, \mathrm{cm}]$ \\
\hline $\begin{array}{l}\text { Sabbagha (average } \\
\text { sized fetuses) [23] }\end{array}$ & GA, HC, AC, FL & $-55.3-16.35 *(\mathrm{GA}+\mathrm{HC}+2 * \mathrm{AC}+\mathrm{FL})+0.25838 *(\mathrm{GA}+\mathrm{HC}+2 * \mathrm{AC}+\mathrm{FL})^{\wedge} 2[\mathrm{~g}, \mathrm{~cm}]$ \\
\hline Warsof [32] & $\mathrm{BPD}, \mathrm{AC}$ & $10^{\wedge}\left(-1.599+0.144^{*} \mathrm{BPD}+0.032 * \mathrm{AC}-0.000111^{*} \mathrm{BPD}^{\wedge} 2 * \mathrm{AC}\right)[\mathrm{kg}, \mathrm{cm}]$ \\
\hline Woo [34] & $\mathrm{BPD}, \mathrm{AC}, \mathrm{FL}$ & $\begin{array}{l}10^{\wedge}\left(1.13705+0.15549 * \mathrm{BPD}+0.0464 * \mathrm{AC}-0.00279682 * \mathrm{BPD}^{*} \mathrm{AC}+0.037769 * \mathrm{FL}\right. \\
-0.000494529 * \mathrm{AC} * \mathrm{FL})[\mathrm{g}, \mathrm{cm}]\end{array}$ \\
\hline Vintzileos [31] & $\mathrm{BPD}, \mathrm{AC}$ & $10^{\wedge}\left(1.879+0.084 * \mathrm{BPD}+0.026^{*} \mathrm{AC}\right)[\mathrm{g}, \mathrm{cm}]$ \\
\hline Persson [17] & $\mathrm{BPD}, \mathrm{AD}, \mathrm{FL}$ & $\mathrm{BPD}^{\wedge} 0.972 *((\mathrm{AD} 1+\mathrm{AD} 2) / 2)^{\wedge} 1.743^{*} \mathrm{FL}^{\wedge} 0.367^{*} 10^{\wedge}(-2.646)[\mathrm{g}, \mathrm{cm}]$ \\
\hline Schild II [24] & $\mathrm{HC}, \mathrm{AC}, \mathrm{FL}$ & $5,381.193+150.324 * \mathrm{HC}+2.069 * \mathrm{FL}^{\wedge} 3+0.0232 * \mathrm{AC}^{\wedge} 3-6,235.478 * \log (\mathrm{HC})[\mathrm{g}, \mathrm{cm}]$ \\
\hline Scott [26] & $\mathrm{HC}, \mathrm{AC}, \mathrm{FL}$ & $10^{\wedge}\left(0.66^{*} \log (\mathrm{HC})+1.04 * \log (\mathrm{AC})+0.985 * \log (\mathrm{FL})\right)[\mathrm{g}, \mathrm{cm}]$ \\
\hline Siemer [29] & $\mathrm{BPD}, \mathrm{AC}, \mathrm{FL}$ & $-5,948.336+2,101.261 * \mathrm{LN}(\mathrm{AC})+15.613 * \mathrm{FL}^{\wedge} 2+0.0577 * \mathrm{BPD}^{\wedge} 3[\mathrm{~g}, \mathrm{~cm}]$ \\
\hline Thurnau [30] & $\mathrm{BPD}, \mathrm{AC}$ & $\left(9.337 * \mathrm{BPD}^{*} \mathrm{AC}\right)-229[\mathrm{~g}, \mathrm{~cm}]$ \\
\hline Weiner I [33] & $\mathrm{HC}, \mathrm{AC}, \mathrm{FL}$ & $10^{\wedge}(1.6961+0.02253 * \mathrm{HC}+0.01645 * \mathrm{AC}+0.06439 * \mathrm{FL})[\mathrm{g}, \mathrm{cm}]$ \\
\hline Weiner II [33] & $\mathrm{HC}, \mathrm{AC}$ & $10^{\wedge}\left(1.6575+0.04035^{*} \mathrm{HC}+0.01285^{*} \mathrm{AC}\right)[\mathrm{g}, \mathrm{cm}]$ \\
\hline Mielke I [20] & $\mathrm{BDP}, \mathrm{AD}, \mathrm{FL}$ & $\begin{array}{l}\mathrm{e}^{\wedge}\left(3.067510+0.01677^{*} \mathrm{BPD}+0.000412^{*} \mathrm{ATD}^{\wedge} 2+0.040611^{*} \mathrm{FL}-0.000000006027957\right. \\
\left.* \mathrm{BPD}^{\wedge} 2 * \mathrm{ATD}^{\wedge} 2-0.000005086^{*} \mathrm{ATD}^{\wedge} 2 * \mathrm{FL}\right)[\mathrm{g}, \mathrm{cm}]\end{array}$ \\
\hline Mielke II [19] & BPD, ATD, FL & $\begin{array}{l}\mathrm{e}^{\wedge}\left(3.704706+0.033276^{*} \mathrm{BPD}+0.000093048^{*} \mathrm{ATD}^{\wedge} 2+0.010570 * \mathrm{FL}-\right. \\
\left.0.00000002477864 * \mathrm{BPD}^{\wedge} 2 * \mathrm{ATD}^{\wedge} 2+0.000002009^{*} \mathrm{ATD}^{\wedge} 2^{*} \mathrm{FL}\right)[\mathrm{g}, \mathrm{cm}]\end{array}$ \\
\hline
\end{tabular}

$\mathrm{AC}=$ Abdominal circumference; $\mathrm{HC}=$ head circumference; $\mathrm{FL}=$ femur length; $\mathrm{BPD}=$ biparietal diameter; $\mathrm{AD}=$ abdominal diameter; GA = gestational age, $\mathrm{MW}=$ maternal weight. 


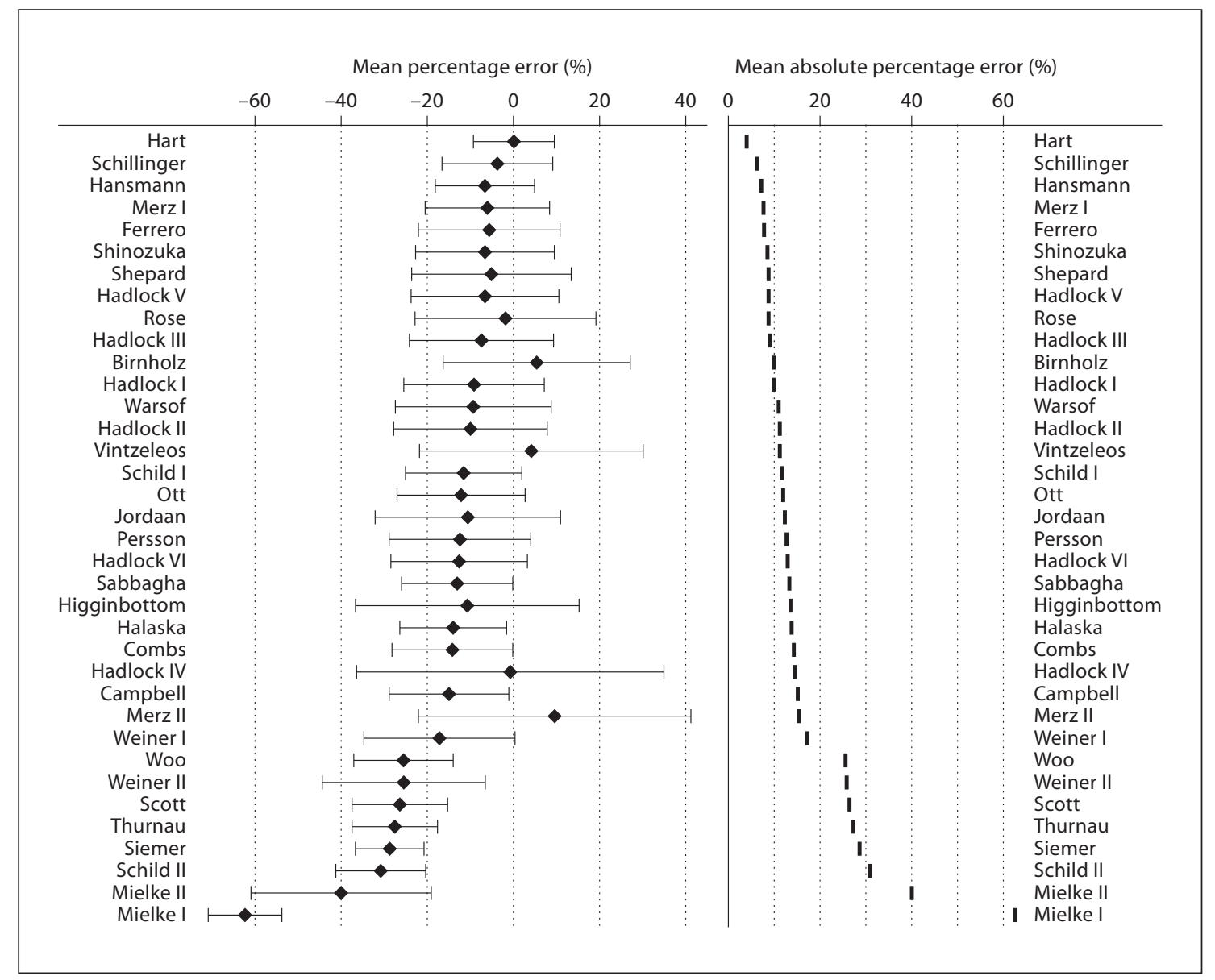

Fig. 1. MPEs, their 95\% limits of agreement, and the MAPEs of 36 analysed formulae.

Table 2. Clinical parameters of the study population

Maternal age, years, median (range)

Maternal weight, $\mathrm{kg}$, median (range)

Para, median (range)

Gestational age, weeks, median (range)

Fetal BW, g, median (range)

Fetal BW $\geq 4,000 \mathrm{~g}, \mathrm{n}$

Fetal BW $\geq 4,300 \mathrm{~g}, \mathrm{n}$

Fetal BW $\geq 4,500 \mathrm{~g}, \mathrm{n}$

Days between US examination and delivery in days, median (range)

Birth within 1 day after ultrasound examination, $n$

Birth within 2-5 days after ultrasound examination, $\mathrm{n}$

Birth within 6-7 days after ultrasound examination, $\mathrm{n}$

Operators performing the ultrasound examination, $n$

Operators with $>3$ years of experience in obstetrical ultrasound, $n$
$32.9(17.1-46.0)$

$81.0(53.0-139.0)$

$1(0-5)$

$40.2(36.0-42.3)$

$4,200.0(4,000.0-5,080.0)$

$350 ; 100 \%$

$120 ; 34.3 \%$

$29 ; 13.4 \%$

$1(0-7)$

$183(52.3 \%)$

$136(38.9 \%)$

$31(8.8 \%)$

39

$10(25.6 \%)$ 
Table 3. Fetal weight estimation according to 36 commonly used weight estimation formulae

\begin{tabular}{|c|c|c|c|}
\hline Formula & MPE, \% & $\mathrm{CI}$ & MAPE, \% \\
\hline Hart & $0.3 \pm 4.8$ & $-0.2 ; 0.8$ & $3.9 \pm 2.8$ \\
\hline Schillinger & $-3.7 \pm 6.6$ & $-4.4 ;-3.0$ & $6.1 \pm 4.5$ \\
\hline Hansmann & $-6.5 \pm 5.8$ & $-7.1 ;-5.9$ & $7.2 \pm 4.9$ \\
\hline Merz & $-6.0 \pm 7.2$ & $-6.8 ;-5.3$ & $7.5 \pm 5.7$ \\
\hline Ferrero & $-5.4 \pm 8.3$ & $-6.3 ;-4.5$ & $7.6 \pm 6.3$ \\
\hline Shinozuka & $-6.3 \pm 8.1$ & $-7.2 ;-5.5$ & $8.3 \pm 6.0$ \\
\hline Shepard & $-4.8 \pm 9.4$ & $-5.8 ;-3.8$ & $8.6 \pm 6.2$ \\
\hline Hadlock V & $-6.7 \pm 8.7$ & $-7.6 ;-5.8$ & $8.7 \pm 6.7$ \\
\hline Rose & $-1.6 \pm 10.6$ & $-2.7 ;-0.5$ & $8.8 \pm 6.1$ \\
\hline Hadlock III & $-7.3 \pm 8.5$ & $-8.2 ;-6.4$ & $9.1 \pm 6.6$ \\
\hline Birnholz & $5.5 \pm 11$ & $4.4 ; 6.7$ & $9.9 \pm 7.2$ \\
\hline Hadlock I & $-9.0 \pm 8.3$ & $-9.9 ;-8.2$ & $10.0 \pm 7.0$ \\
\hline Warsof & $-9.3 \pm 9.1$ & $-10.3 ;-8.4$ & $10.6 \pm 7.5$ \\
\hline Hadlock II & $-10.0 \pm 9.0$ & $-10.9 ;-9.1$ & $11.1 \pm 7.6$ \\
\hline Vintzeleos & $4.4 \pm 13.2$ & $3.0 ; 5.8$ & $11.1 \pm 8.4$ \\
\hline Schild sex-specific & $-11.5 \pm 6.8$ & $-12.2 ;-10.8$ & $11.7 \pm 6.4$ \\
\hline Ott & $-11.8 \pm 7.6$ & $-12.6 ;-11.0$ & $12.1 \pm 7.1$ \\
\hline Jordaan & $-10.2 \pm 10.9$ & $-11.3 ;-9.1$ & $12.3 \pm 8.5$ \\
\hline Persson & $-12.3 \pm 8.4$ & $-13.2 ;-11.4$ & $12.7 \pm 7.8$ \\
\hline Hadlock VI & $-12.6 \pm 8.1$ & $-13.5 ;-11.8$ & $12.9 \pm 7.6$ \\
\hline Sabbagha & $-13.0 \pm 6.5$ & $-13.7 ;-12.3$ & $13.1 \pm 6.3$ \\
\hline Higginbottom & $-10.5 \pm 13.1$ & $-11.9 ;-9.1$ & $13.5 \pm 10.0$ \\
\hline Halaska & $-13.7 \pm 6.3$ & $-14.4 ;-13.0$ & $13.8 \pm 6.2$ \\
\hline Combs & $-14.1 \pm 7.1$ & $-14.8 ;-13.4$ & $14.1 \pm 7.0$ \\
\hline Hadlock IV & $-0.6 \pm 18.2$ & $-2.5 ; 1.3$ & $14.3 \pm 11.1$ \\
\hline Campbell & $-14.9 \pm 7.1$ & $-15.6 ;-14.2$ & $14.9 \pm 7.1$ \\
\hline Merz II & $9.6 \pm 16.1$ & $7.9 ; 11.3$ & $15.3 \pm 10.8$ \\
\hline Weiner I & $-17.1 \pm 8.8$ & $-18.0 ;-16.2$ & $17.2 \pm 8.6$ \\
\hline Woo & $-25.4 \pm 5.9$ & $-26.0 ;-24.8$ & $25.4 \pm 5.9$ \\
\hline Weiner II & $-25.5 \pm 9.6$ & $-26.5 ;-24.5$ & $25.6 \pm 9.2$ \\
\hline Scott & $-26.2 \pm 5.6$ & $-26.8 ;-25.6$ & $26.2 \pm 5.6$ \\
\hline Thurnau & $-27.4 \pm 5.0$ & $-27.9 ;-26.9$ & $27.4 \pm 5.0$ \\
\hline Siemer & $-28.6 \pm 4.1$ & $-29.0 ;-28.2$ & $28.6 \pm 4.1$ \\
\hline Schild & $-30.7 \pm 5.3$ & $-31.3 ;-30.1$ & $30.7 \pm 5.3$ \\
\hline Mielke II & $-39.8 \pm 10.7$ & $-40.9 ;-38.7$ & $39.8 \pm 10.7$ \\
\hline Mielke I & $-62.2 \pm 4.3$ & $-62.7 ;-61.8$ & $62.2 \pm 4.3$ \\
\hline
\end{tabular}

For each of the 36 formulae, MPE $(\mathrm{EFW}-\mathrm{BW}) / \mathrm{BW} \times 100$ and MAPE $(|\mathrm{EFW}-\mathrm{BW}| / \mathrm{BW} \times 100)$ and their standard deviation (SD) are demonstrated. In addition, the confidence interval is shown for the PE. The results are sorted according to the APE. Median BW was 4,200.0 g.

Hadlock IV approach, the CI included 0, indicating a non-significant systematic error. Consistently, MAPE was smallest with the Hart approach (3.9\%) and biggest with the Mielke I formula (62.2\%). MPEs according to 95\% limits of agreement and MAPEs are also demonstrated in figure 1.
Table 4. Frequency distribution of differences between EFW and BW

\begin{tabular}{|c|c|c|c|c|}
\hline \multirow[t]{2}{*}{ Formula } & \multicolumn{4}{|c|}{ Within } \\
\hline & $5 \%$ & $10 \%$ & $20 \%$ & $30 \%$ \\
\hline Hart & 69.5 & 95.6 & 100.0 & 100.0 \\
\hline Schillinger & 48.6 & 81.4 & 99.1 & 100.0 \\
\hline Hansmann & 4.6 & 69.4 & 24.6 & 1.4 \\
\hline Merz I & 5.7 & 65.4 & 25.1 & 3.4 \\
\hline Ferrero & 42.3 & 68.6 & 95.4 & 99.7 \\
\hline Shinozuka & 5.1 & 60.6 & 29.4 & 4.6 \\
\hline Shepard & 4.3 & 61.4 & 28.6 & 5.4 \\
\hline Hadlock V & 4.3 & 58.6 & 30.0 & 6.9 \\
\hline Rose & 2.0 & 60.9 & 30.3 & 6.3 \\
\hline Hadlock III & 2.9 & 58.0 & 32.0 & 6.9 \\
\hline Birnholz & 3.1 & 52.0 & 36.0 & 7.7 \\
\hline Hadlock I & 4.0 & 48.6 & 37.4 & 9.7 \\
\hline Warsof & 3.7 & 46.6 & 37.4 & 11.7 \\
\hline Hadlock II & 1.7 & 48.9 & 36.0 & 12.0 \\
\hline Vintzeleos & 26.9 & 50.9 & 85.4 & 98.0 \\
\hline Schild I & 1.7 & 39.4 & 47.7 & 10.9 \\
\hline Ott & 22.0 & 42.0 & 83.7 & 100.0 \\
\hline Jordaan & 25.4 & 45.4 & 79.7 & 96.3 \\
\hline Persson & 2.0 & 37.4 & 42.9 & 16.0 \\
\hline Hadlock VI & 2.3 & 36.6 & 41.1 & 18.3 \\
\hline Sabbagha & 10.9 & 33.7 & 84.9 & 100.0 \\
\hline Higginbottom & 3.1 & 39.1 & 32.3 & 17.7 \\
\hline Halaska & 0.0 & 27.7 & 56.0 & 15.7 \\
\hline Combs & 9.1 & 29.1 & 77.7 & 99.1 \\
\hline Hadlock IV & 2.6 & 40.3 & 29.7 & 16.6 \\
\hline Campbell & 5.1 & 26.9 & 78.0 & 96.6 \\
\hline Merz II & 18.9 & 38.3 & 70.0 & 89.7 \\
\hline Weiner I & 0.0 & 21.7 & 39.7 & 31.1 \\
\hline Woo & 0.0 & 0.3 & 20.3 & 77.1 \\
\hline Weiner II & 0.6 & 3.7 & 23.1 & 38.0 \\
\hline Scott & 0.0 & 0.0 & 14.6 & 58.9 \\
\hline Thurnau & 0.0 & 0.0 & 6.3 & 64.6 \\
\hline Siemer & 0.0 & 0.0 & 0.9 & 61.7 \\
\hline Schild II & 0.0 & 0.0 & 2.0 & 41.7 \\
\hline Mielke II & 0.6 & 0.9 & 3.7 & 18.6 \\
\hline Mielke I & 0.0 & 0.0 & 0.0 & 0.0 \\
\hline
\end{tabular}

Differences were demonstrated as proportion of cases with a discrepancy within $\pm 5 \%, \pm 10 \%, \pm 20 \%$ and $\pm 30 \%$. The results are sorted according to the APE listed in table 3.

\section{Frequency Distribution of Differences between EFW and $B W$}

Table 4 shows the frequency distribution of the differences between EFW and BW for each formula. At all discrepancy levels between \pm 5 and $\pm 30 \%$, the Hart formula was most accurate. In $95.6 \%$ of the cases, the dis- 
Table 5. Detection and false positive rates in screening for fetuses with a fetal BW of 4,000, 4,300 and 4,500 g or more by 36 commonly used weight estimation formulae

\begin{tabular}{|c|c|c|c|c|c|}
\hline \multirow[t]{2}{*}{ Formula } & \multirow{2}{*}{$\begin{array}{l}\geq 4,000 \mathrm{~g}, \% \\
\text { DR }\end{array}$} & \multicolumn{2}{|c|}{$\geq 4,300 \mathrm{~g}, \%$} & \multicolumn{2}{|c|}{$\geq 4,500 \mathrm{~g}, \%$} \\
\hline & & $\mathrm{DR}$ & FPR & $\mathrm{DR}$ & FPR \\
\hline Hart & $100(203)$ & $42.6(29)$ & $17.8(24)$ & $0(0)$ & $0(0)$ \\
\hline Schillinger & $64.3(225)$ & $45(54)$ & $13.5(31)$ & $38.3(18)$ & $3(9)$ \\
\hline Hansmann & $48(168)$ & $15.8(19)$ & $3(7)$ & $10.6(5)$ & $0.3(1)$ \\
\hline Merz I & $52.6(184)$ & $33.3(40)$ & $8.3(19)$ & $25.5(12)$ & $1.7(5)$ \\
\hline Ferrero & $56.6(198)$ & $45.8(55)$ & $10(23)$ & $40.4(19)$ & $3(9)$ \\
\hline Shinozuka & $46.6(163)$ & $34.2(41)$ & $12.2(28)$ & $27.7(13)$ & $3.6(11)$ \\
\hline Shepard & $56(196)$ & $41.7(50)$ & $20(46)$ & $40.4(19)$ & $9.6(29)$ \\
\hline Hadlock V & $51.1(179)$ & $35.8(43)$ & $11.7(27)$ & $31.9(15)$ & $5(15)$ \\
\hline Rose & $61.7(216)$ & $54.2(65)$ & $31.7(73)$ & $55.3(26)$ & $22.4(68)$ \\
\hline Hadlock III & $43.4(152)$ & $31.7(38)$ & $10(23)$ & $29.8(14)$ & $3.3(10)$ \\
\hline Birnholz & $80.6(282)$ & $80.8(97)$ & $57.4(132)$ & $83(39)$ & 45.9 (139) \\
\hline Hadlock I & $38.3(134)$ & $24.2(29)$ & $6.5(15)$ & $27.7(13)$ & $2(6)$ \\
\hline Warsof & $39.1(137)$ & $26.7(32)$ & $6.5(15)$ & $27.7(13)$ & $3(9)$ \\
\hline Hadlock II & 34 (119) & $22.5(27)$ & $6.5(15)$ & $19.1(9)$ & $2.3(7)$ \\
\hline Vintzileos & $73.4(257)$ & $50.8(61)$ & $63(145)$ & $51.1(24)$ & $46.5(141)$ \\
\hline Schild I & $21.4(75)$ & $8.3(10)$ & $0.9(2)$ & $2.1(1)$ & $0.7(2)$ \\
\hline Ott & $23.7(83)$ & $17.5(21)$ & $0(0)$ & $17(8)$ & $0(0)$ \\
\hline Jordaan & $36.6(128)$ & $39.2(47)$ & $7.4(17)$ & $46.8(22)$ & $4.6(14)$ \\
\hline Persson & $24.6(86)$ & $15.8(19)$ & $1.3(3)$ & $19.1(9)$ & $1(3)$ \\
\hline Hadlock VI & $22.3(78)$ & $16.7(20)$ & $0.9(2)$ & $12.8(6)$ & $0(0)$ \\
\hline Sabbagha & $15.4(54)$ & $6.7(8)$ & $0(0)$ & $2.1(1)$ & $0(0)$ \\
\hline Higginbottom & $40.3(141)$ & 40.8 (49) & $11.3(26)$ & $40.4(19)$ & $8.9(27)$ \\
\hline Halaska & $9.4(33)$ & $2.5(3)$ & $0.4(1)$ & $2.1(1)$ & $0(0)$ \\
\hline Combs & $13.7(48)$ & $8.3(10)$ & $0(0)$ & $2.1(1)$ & $0(0)$ \\
\hline Hadlock IV & $58.6(205)$ & $64.2(77)$ & $36.5(84)$ & $74.5(35)$ & $31(94)$ \\
\hline Campbell & $8(28)$ & $0(0)$ & $0(0)$ & $0(0)$ & $0(0)$ \\
\hline Merz II & $80.3(281)$ & $50.8(61)$ & $78.3(180)$ & $51.1(24)$ & $59.4(180)$ \\
\hline Weiner I & $12.6(44)$ & $10(12)$ & $0.4(1)$ & $8.5(4)$ & $0.3(1)$ \\
\hline Woo & $0.3(1)$ & $0(0)$ & $0(0)$ & $0(0)$ & $0(0)$ \\
\hline Weiner II & 4.9 (17) & $3.3(4)$ & $0.4(1)$ & $4.3(2)$ & $0.3(1)$ \\
\hline Scott & $0(0)$ & $0(0)$ & $0(0)$ & $0(0)$ & $0(0)$ \\
\hline Thurnau & $0(0)$ & $0(0)$ & $0(0)$ & $0(0)$ & $0(0)$ \\
\hline Siemer & $0(0)$ & $0(0)$ & $0(0)$ & $0(0)$ & $0(0)$ \\
\hline Schild II & $0(0)$ & $0(0)$ & $0(0)$ & $0(0)$ & $0(0)$ \\
\hline Mielke II & $0.6(2)$ & $0(0)$ & $0(0)$ & $0(0)$ & $0(0)$ \\
\hline Mielke I & $0(0)$ & $0(0)$ & $0(0)$ & $0(0)$ & $0(0)$ \\
\hline
\end{tabular}

The results are sorted according to the MAPE listed in table 3.

crepancy between EFW and BW was within 10\%. For comparison, only with 12 of the 36 formulae the discrepancy was within $10 \%$ in more than half of the cases.

\section{Screening for Fetuses with a BW of 4,000, 4,300 and} 4,500 g or More

Table 5 shows the detection and false positive rates in screening for fetuses with a fetal BW of 4,000, 4,300 and
$4,500 \mathrm{~g}$ or more. The mean detection rates for fetuses with a BW $\geq 4,000, \geq 4,300$ and $\geq 4,500$ g were 29,24 and $22 \%$, respectively, and false positive rates were $12 \%$ (for $\geq 4,300 \mathrm{~g}$ ) and $7 \%$ (for $\geq 4,500 \mathrm{~g}$ ). Only 11 formulae detected more than half of the fetuses with 4,000 g and more and only 5 formulae correctly identified more than half of the fetuses with a BW of $4,500 \mathrm{~g}$ or more. The Hart formula correctly identified all fetuses with a BW 
$\geq 4,000 \mathrm{~g}$ but none of the fetuses with a $\mathrm{BW} \geq 4,500 \mathrm{~g}$. The highest detection rate for fetuses with a BW $\geq 4,500$ $\mathrm{g}$ was achieved with the Hadlock IV formula (74.5\%) but for a false positive rate of $31.5 \%$.

\section{Discussion}

In the present study we compared 36 weight estimation formulae in a population of 350 fetuses weighing $\geq 4,000$ g. Only with 2 formulae (Hard and Hadlock IV) the systematic error was not significantly different from 0 . However, only the Hart approach combined a small MPE (or systematic error) with a small standard deviation and a small MAPE. Interestingly, the detection rate for fetuses with a BW $\geq 4,000$ and $\geq 4,500 \mathrm{~g}$ was 100 and $0 \%$ with the Hart formula. MPE and MAPE were smallest with the Hart formula (MPE 0.3\%, MAPE 3.9\%). Among all formulae the mean detection rates for fetuses with a BW $\geq 4,000, \geq 4,300$ and $\geq 4,500$ g were low $(29,24$ and $22 \%$, respectively) for impressively high false positive rates (12 and 7\%).

The advantages of certain ultrasound-based formulae have been critically analyzed. Most studies have found that, regardless of the applied formula, accuracy of the EFW decreases at the extremes of FW of $>4,000$ and $<1,500 \mathrm{~g}[11,12,43,44]$. However, these two groups of neonates require a higher accuracy of weight estimation for the obstetrical management. Siemer et al. [45] evaluated 11 weight estimation formulae in a population of 1,941 pregnancies. Among 211 newborns $\geq 4,000$ g, MPE and MAPE ranged from 5.2 and $7.5 \%$ with the Merz formula to 14.5 and $14.9 \%$ with the Campbell formula, respectively. These results are consistent with our study where the Merz formula achieved a MPE of $6.0 \%$ and a MAPE of $7.5 \%$.

Combs et al. [46] compared the accuracy of 31 formulae in predicting fetal macrosomia in women with diabetes. In this study, the Ott formula was superior with a MPE and MAPE of -2.9 and $8.2 \%$. The detection rate was $45 \%$ for fetuses with a BW $\geq 4,000 \mathrm{~g}$. Nevertheless, none of the formulae proved significant advantage over others in assessing weight in fetal macrosomia. In our study the Ott formula showed a substantially higher MPE (11.8\%), MAPE (12.1\%) and a much lower detection rate for fetuses $\geq 4,000 \mathrm{~g}(23.7 \%)$. There are methodological differences between these two studies. Combs et al. included intervals between sonogram and delivery of up to 14 days with a mean difference of almost 6 days and applied a correction factor in each case according to the temporal dif- ference. In our study the median temporal difference was only 1 day which was shown to be irrelevant for the accuracy of FW estimation [47]. The MAPEs in the study of Combs et al. were much higher than in our study, which questions the reliability of these correction factors. In addition, one can speculate that this discrepancy is caused by the preselection of diabetic pregnancies in the study of Combs et al.

In the present study, the formulae of Siemer, Scott, Thurnau, Weiner and Mielke showed the highest MPE and MAPE. This observation is not surprising because these formulae were exclusively developed on and dedicated to small fetuses, however, the dimension of the demonstrated error is remarkable. This should draw clinicians' attention to the purpose of the used formula to prevent avoidable errors.

Several workgroups have focused on the improvement of FW estimation in macrosomic fetuses. The recently published Hart formula was especially developed for large fetuses. The authors restricted the use to fetuses with an $\mathrm{AC} \geq 35.1 \mathrm{~cm}$. Indeed, in our study the MPE $(-0.3 \%)$ and MAPE $(3.9 \%)$ were lowest with the Hart formula which was consistent to their results (MPE -1.8 and MAPE 3.6\%) [42]. In our study, the Hart formula detected all fetuses $\geq 4,000 \mathrm{~g}$. Surprisingly, the detection rate fell to $0 \%$ for fetuses $\geq 4,500 \mathrm{~g}$ indicating a low reliability of the Hart formula above this threshold. This observation demonstrates the general problems of logistic regression models to predict FW: the evaluated equations were designed on the basis of data collected in small samples from a limited number of centres using a non-standardised retrospective data collection. The best-fit formula could only be as accurate and representative as it was in the formula finding population.

Melamed et al. [12] compared 26 weight estimation formulae and found that formulae based on three and more biometric indices were more accurate. In our study, this could not be confirmed. Four of the 5 formulae (Schillinger, Ferrero, Hansmann and Merz) with the lowest MAPE (3.9-7.6\%) were based on the measurement of only two biometric measurements. Some authors even argue that the isolated measurement of the fetal $\mathrm{AC}$ is as good as using the weight estimation formulae in predicting macrosomia $[3,48]$. However, it is the measurement of the AC that accounts for the biggest proportion of the systematic and the random error $[49,50]$. The observer variability of the $\mathrm{AC}$, which can be considered as a marker for the reproducibility of a measurement, is estimated to produce a random error of $3.5 \%$ of the EFW [51, 52]. The measurement of the fetal head size at term or during 
labour is also associated with a substantial error, as it is particularly difficult to correctly assess the dimensions of the engaged fetal head [53]. The Ferrero formula is only based on AC and FL and accounts to the 5 formulae with smallest MPE (5.4\%) and MAPE (7.6\%) in our study [39].

Nahum and Stanislaw [54] and similarly Mazouni et al. [55] combined sonographic data with maternal and pregnancy-specific variables such as gestational age, parity, fetal sex, maternal height and weight to increase the detection rate of macrosomic fetuses. Both studies showed some improvement but in a recent independent study these results were not confirmed [56].

A recent discussion concentrates on the value of three-dimensional (3D) ultrasound in evaluating fetal body composition and consecutively in estimating FW. Lee et al. $[57,58]$ recently showed that in late stage pregnancies the fetal percentage of body fat is most highly correlated with the fractional thigh volume assessed by 3D ultrasound. However, Hasenoehrl et al. [59] compared different formulae using 2D (Hansmann, Merz, Hadlock) and 3D ultrasound (Schild, Liang, Chang). The 3D Schild formula showed a moderate improvement of accuracy but the other 3D formulae demonstrated poor results. Especially in fetuses of diabetic mothers the disproportionate contribution of fat to fetal body weight applying conventional weight estimation formulae may, in theory, lead to an overestimation of their weights [60]. 2D measurements of fatty tissue failed to demonstrate an improvement of the diagnosis of fetal macrosomia [61, 62]. In addition, Alsulyman et al. [63] could not find significant differences in MAPE between infants of women with diabetes and those born of women without diabetes.

On clinical grounds, the most important question remains whether it is applicable to use FW estimation as a screening test for fetuses with an increased risk for shoulder dystocia. In spite of some controversies about the relationship between fetal size and shoulder dystocia [43, $64,65]$, most guidelines refer in their recommendations for risk groups like diabetic mothers to a threshold of $\mathrm{EFW} \geq 4,500 \mathrm{~g}[66,67]$. In our study, none of the formulae detected all cases with a $\mathrm{BW} \geq 4,500 \mathrm{~g}$. Among all tested formulae, the mean detection rate was only $22 \%$. The highest detected rate of $83 \%$ was achieved with the Birnholz formula but for a false positive rate of $46 \%$. The only other formula that identified at least $70 \%$ of the affected fetuses was the Hadlock IV formula (74.5\%) but also for a clinically not applicable false positive rate of $31 \%$. It gets obvious how questionable it is to rely solely on FW estimation in predicting macrosomia and how important it is to search for new approaches to increase the accuracy of FW estimation.

In summary, the prediction of macrosomia is a clinically important but unsolved problem. Some formulae were better than others but none reached an acceptable detection and false positive rate in screening for fetuses $\geq 4,500 \mathrm{~g}$ that could lead to clinical recommendation.

\section{References}

$>1$ Oral E, Cagdas A, Gezer A, Kaleli S, Aydinli K, Ocer F: Perinatal and maternal outcomes of fetal macrosomia. Eur J Obstet Gynecol Reprod Biol 2001;99:167-171.

$\checkmark 2$ Sacks DA, Chen W: Estimating fetal weight in the management of macrosomia. Obstet Gynecol Surv 2000;55:229-239.

$>3$ Coomarasamy A, Connock M, Thornton J, Khan KS: Accuracy of ultrasound biometry in the prediction of macrosomia: a systematic quantitative review. BJOG 2005;112: 1461-1466.

$\checkmark 4$ Neiger R: Fetal macrosomia in the diabetic patient. Clin Obstet Gynecol 1992;35:138150.

5 Zimmer EZ, Divon MY: Sonographic diagnosis of IUGR macrosomia. Clin Obstet Gynecol 1992;35:172-184.
-6 Landon MB, Gabbe SG, Sachs L: Management of diabetes mellitus and pregnancy: a survey of obstetricians and maternal-fetal specialists. Obstet Gynecol 1990;75:635640.

7 Ecker JL, Greenberg JA, Norwitz ER, Nadel AS, Repke JT: Birth weight as a predictor of brachial plexus injury. Obstet Gynecol 1997; 89:643-647.

8 Gilbert WM, Nesbitt TS, Danielsen B: Associated factors in 1,611 cases of brachial plexus injury. Obstet Gynecol 1999;93:536-540.

-9 Peleg D, Hasnin J, Shalev E: Fractured clavicle and Erb's palsy unrelated to birth trauma. Am J Obstet Gynecol 1997;177:1038-1040.

10 Surkan PJ, Hsieh CC, Johansson AL, Dickman PW, Cnattingius S: Reasons for increasing trends in large for gestational age births. Obstet Gynecol 2004;104:720-726.
11 Dudley NJ: A systematic review of the ultrasound estimation of fetal weight. Ultrasound Obstet Gynecol 2005;25:80-89.

12 Melamed N, Yogev Y, Meizner I, Mashiach R, Bardin R, Ben-Haroush A: Sonographic fetal weight estimation: which model should be used? J Ultrasound Med 2009;28:617-629.

13 Halaska MG, Vlk R, Feldmar P, Hrehorcak M, Krcmar M, Mlcochova H, et al: Predicting term birth weight using ultrasound and maternal characteristics. Eur J Obstet Gynecol Reprod Biol 2006;128:231-235.

14 Hansmann M, Schumacher $H$, Voigt U: Mehrparametrische nicht lineare Gewichtsschätzung mittels Ultraschall unter Berücksichtigung des Gestationsalters; in Kratochwil A, Reinold E (eds): Ultraschalldiagnostik. Stuttgart, Thieme, 1978, pp 69-71. 
15 Higginbottom J: Estimation of fetal weight. 29 Siemer J, Hilbert A, Hart N, Meurer B, Ultrasound Med Biol 1977;3:59.

16 Jordaan HV, Dunn LJ: A new method of evaluating fetal growth. Obstet Gynecol 1978;51: 659-665.

17 Marsal K: Antenatal diagnosis of intrauterine growth retardation by ultrasound. Int J Technol Assess Health Care 1992;8(suppl 1):160-169.

18 Merz E, Lieser H, Schicketanz KH, Harle J: Intrauterine fetal weight assessment using ultrasound. A comparison of several weight assessment methods and development of a new formula for the determination of fetal weight (in German). Ultraschall Med 1988;9: 15-24.

19 Mielke G, Pietsch-Breitfeld B, Regele B, Gonser M, Marzusch K: An accurate method for sonographic estimation of the weight of very preterm fetuses. Gynecol Obstet Invest 1997; 43:98-103.

20 Mielke G, Pietsch-Breitfeld B, Salinas R, Risse T, Marzusch K: A new formula for prenatal ultrasonographic weight estimation in extremely preterm fetuses. Gynecol Obstet Invest 1995;40:84-88.

21 Ott WJ, Doyle S, Flamm S, Wittman J: Accurate ultrasonic estimation of fetal weight. Prospective analysis of new ultrasonic formulas. Am J Perinatol 1986;3:307-310.

22 Rose BI, McCallum WD: A simplified method for estimating fetal weight using ultrasound measurements. Obstet Gynecol 1987; 69:671-675.

$\checkmark 23$ Sabbagha RE, Minogue J, Tamura RK, Hungerford SA: Estimation of birth weight by use of ultrasonographic formulas targeted to large-, appropriate-, and small-for-gestational-age fetuses. Am J Obstet Gynecol 1989;160:854-862.

-24 Schild RL, Fell K, Fimmers R, Gembruch U, Hansmann M: A new formula for calculating weight in the fetus of $<$ or $=1,600 \mathrm{~g}$. Ultrasound Obstet Gynecol 2004;24:775-780.

25 Schild RL, Sachs C, Fimmers R, Gembruch U, Hansmann M: Sex-specific fetal weight prediction by ultrasound. Ultrasound $\mathrm{Ob}$ stet Gynecol 2004;23:30-35.

-26 Scott F, Beeby P, Abbott J, Edelman D, Boogert A: New formula for estimating fetal weight below 1,000 g: comparison with existing formulas. J Ultrasound Med 1996;15: 669-672.

-27 Shepard MJ, Richards VA, Berkowitz RL, Warsof SL, Hobbins JC: An evaluation of two equations for predicting fetal weight by ultrasound. Am J Obstet Gynecol 1982;142: 47-54.

28 Shinozuka N, Okai T, Kohzuma S, Mukubo M, Shih CT, Maeda T, et al: Formulas for fetal weight estimation by ultrasound measurements based on neonatal specific gravities and volumes. Am J Obstet Gynecol 1987;157: 1140-1145.
Goecke T, Schild RL: A new sonographic weight formula for fetuses $<$ or $=2,500 \mathrm{~g}$. Ultraschall Med 2009;30:47-51.

-30 Thurnau GR, Tamura RK, Sabbagha R, Depp OR 3rd, Dyer A, Larkin R, et al: A simple estimated fetal weight equation based on realtime ultrasound measurements of fetuses less than thirty-four weeks' gestation. Am J Obstet Gynecol 1983;145:557-561.

31 Vintzileos AM, Campbell WA, Rodis JF, Bors-Koefoed R, Nochimson DJ: Fetal weight estimation formulas with head, abdominal, femur, and thigh circumference measurements. Am J Obstet Gynecol 1987; 157:410-414.

32 Warsof SL, Gohari P, Berkowitz RL, Hobbins JC: The estimation of fetal weight by computer-assisted analysis. Am J Obstet Gynecol 1977;128:881-892.

33 Weiner CP, Sabbagha RE, Vaisrub N, Socol ML: Ultrasonic fetal weight prediction: role of head circumference and femur length. Obstet Gynecol 1985;65:812-817.

- 34 Woo JS, Wan MC: An evaluation of fetal weight prediction using a simple equation containing the fetal femur length. J Ultrasound Med 1986;5:453-457.

35 Schillinger H, MullerR, WodeJ, Kretzschmar $\mathrm{M}$ : Intrauterine weight determination of the fetus using ultrasonics (in German). Arch Gynakol 1975;219:399-401.

36 Birnholz JC: An algorithmic approach to accurate ultrasonic fetal weight estimation. Invest Radiol 1986;21:571-576.

37 Combs CA, Jaekle RK, Rosenn B, Pope M, Miodovnik M, Siddiqi TA: Sonographic estimation of fetal weight based on a model of fetal volume. Obstet Gynecol 1993;82:365370.

38 Campbell S, Wilkin D: Ultrasonic measurement of fetal abdomen circumference in the estimation of fetal weight. Br J Obstet Gynaecol 1975;82:689-697.

39 Ferrero A, Maggi E, Giancotti A, Torcia F, Pachi A: Regression formula for estimation of fetal weight with use of abdominal circumference and femur length: a prospective study. J Ultrasound Med 1994;13:823-833.

40 Hadlock FP, Harrist RB, Carpenter RJ, Deter RL, Park SK: Sonographic estimation of fetal weight. The value of femur length in addition to head and abdomen measurements. Radiology 1984;150:535-540.

41 Hadlock FP, Harrist RB, Sharman RS, Deter RL, Park SK: Estimation of fetal weight with the use of head, body, and femur measurements - a prospective study. Am J Obstet Gynecol 1985;151:333-337.

42 Hart N, Hilbert A, Meurer B, Schrauder M, Schmid M, Siemer J, et al: Macrosomia: a new formula for optimized fetal weight estimation. Ultrasound Obstet Gynecol 2010;35: 42-47.

43 Acker DB, Sachs BP, Friedman EA: Risk factors for shoulder dystocia. Obstet Gynecol 1985;66:762-768.
44 Siemer J, Wolf T, Hart N, Schrauder M, Meurer B, Goecker T, et al: Increased accuracy of fetal weight estimation with a gender-specific weight formula. Fetal Diagn Ther 2008;24: 321-326.

45 Siemer J, Egger N, Hart N, Meurer B, Muller A, Dathe O, et al: Fetal weight estimation by ultrasound: comparison of 11 different formulae and examiners with differing skill levels. Ultraschall Med 2008;29:159-164.

46 Combs CA, Rosenn B, Miodovnik M, Siddiqi TA: Sonographic EFW and macrosomia: is there an optimum formula to predict diabetic fetal macrosomia? J Matern Fetal Med 2000;9:55-61.

-47 Nahum GG, Stanislaw H, Huffaker BJ: Fetal weight gain at term: linear with minimal dependence on maternal obesity. Am J Obstet Gynecol 1995;172:1387-1394.

48 Deter RL, Hadlock FP: Use of ultrasound in the detection of macrosomia: a review. J Clin Ultrasound 1985;13:519-524.

49 Dudley NJ, Chapman E: The importance of quality management in fetal measurement. Ultrasound Obstet Gynecol 2002;19:190196.

50 Smulian JC, Ranzini AC, Ananth CV, Rosenberg JC, Vintzileos AM: Comparison of three sonographic circumference measurement techniques to predict birth weight. Obstet Gynecol 1999;93:692-696.

51 Chang TC, Robson SC, Spencer JA, Gallivan S: Ultrasonic fetal weight estimation: analysis of inter- and intra-observer variability. J Clin Ultrasound 1993;21:515-519.

52 Sarmandal P, Bailey SM, Grant JM: A comparison of three methods of assessing interobserver variation applied to ultrasonic fetal measurement in the third trimester. Br J Obstet Gynaecol 1989;96:1261-1265.

53 Patterson RM: Estimation of fetal weight during labor. Obstet Gynecol 1985;65:330332.

54 Nahum GG, Stanislaw H: Fetal macrosomia is predicted earlier by combination birthweight estimation methods than by ultrasound alone. Ultrasound Obstet Gynecol 2009;34:122.

55 Mazouni C, Rouzier R, Ledu R, Heckenroth H, Guidicelli B, Gamerre M: Development and internal validation of a nomogram to predict macrosomia. Ultrasound Obstet Gynecol 2007;29:544-549.

56 Balsyte D, Schaffer L, Burkhardt T, Wisser J, Kurmanavicius J: Sonographic prediction of macrosomia cannot be improved by combination with pregnancy-specific characteristics. Ultrasound Obstet Gynecol 2009;33: 453-458.

57 Lee W, Balasubramaniam M, Deter RL, Hassan SS, Gotsch F, Kusanovic JP, et al: Fetal growth parameters and birth weight: their relationship to neonatal body composition. Ultrasound Obstet Gynecol 2009;33:441446. 
58 Lee W, Balasubramaniam M, Deter RL, Hassan SS, Gotsch F, Kusanovic JP, et al: Fractional limb volume - a soft tissue parameter of fetal body composition: validation, technical considerations and normal ranges during pregnancy. Ultrasound Obstet Gynecol 2009;33:427-440.

59 Hasenoehrl G, Pohlhammer A, Gruber R, Staudach A, Steiner H: Fetale Gewichtsschatzung mittels 2-D- und 3-D-Ultraschall: Vergleich von 6 Schatzformeln. Ultraschall Med 2009;30:585-590.

-60 Crane SS, Avallone DA, Thomas AJ, Catalano PM: Sonographic estimation of fetal body composition with gestational diabetes mellitus at term. Obstet Gynecol 1996;88:849854.
61 Sood AK, Yancey M, Richards D: Prediction of fetal macrosomia using humeral soft tissue thickness. Obstet Gynecol 1995;85:937940.

62 Rotmensch S, Celentano C, Liberati M, Malinger G, Sadan O, Bellati U, et al: Screening efficacy of the subcutaneous tissue width/femur length ratio for fetal macrosomia in the non-diabetic pregnancy. Ultrasound Obstet Gynecol 1999;13:340-344.

63 Alsulyman OM, Ouzounian JG, Kjos SL: The accuracy of intrapartum ultrasonographic fetal weight estimation in diabetic pregnancies. Am J Obstet Gynecol 1997;177:503-506.
64 Gross TL, Sokol RJ, Williams T, Thompson K: Shoulder dystocia: a fetal-physician risk. Am J Obstet Gynecol 1987;156:1408-1418.

65 Naef RW 3rd, Martin JN Jr: Emergent management of shoulder dystocia. Obstet Gynecol Clin North Am 1995;22:247-259.

66 Sokol RJ, Blackwell SC: ACOG practice bulletin: shoulder dystocia. No. 40, November 2002 (replaces practice pattern No. 7, October 1997). Int J Gynaecol Obstet 2003;80:8792.

67 Chauhan SP, Gherman R, Hendrix NW, Bingham JM, Hayes E: Shoulder dystocia: comparison of the ACOG practice bulletin with another national guideline. Am J Perinatol 2009, epub ahead of print. 